\title{
Rehabilitation of Mid Facial Tissue Defects Due to Gun Shot Injury- A Case Report
}

\author{
Brig E Mahesh Gowd ${ }^{1}$, Gopalakrishnan V2* and Kaushik SK \\ ${ }^{1}$ Department of Prosthodontics, Dy Comdt \& CMDC (WC), India \\ ${ }^{2}$ Department of Oral \& Maxillofacial surgery, 3 Corps Dental unit, India \\ ${ }^{3}$ Department of Oral \& Maxillofacial surgery, CO AFDC, India
}

Submission: December 21, 2017; Published: January 08, 2018

*Corresponding author: V Gopalakrishnan, DO \& Graded Spl (Oral\& Maxillofacial surgery), 3 Corps Dental unit, Dimapur, India,

Email: gopalanagarajan2005@yahoo.com

\section{Abstract}

The extensive damage of the tissues of face and oro-facial region possesses great challenge for the treating dental surgeon to rehabilitate towards near perfect condition physiologically, functionally and esthetically $[1,2]$.

The initial analysis towards the extent of damage is difficult to assess and later due to increase in chances of infection, ischemia and necrosis there are reduced chances towards faster healing, which complicates the reconstruction/rehabilitation part.

The rehabilitation of the defects usually involves initial stabilization, definitive reconstruction and later secondary reconstruction by surgical or prosthodontical techniques of restoring the lost tissues/defects. The latest surgical protocol implies the immediate surgical reconstruction as a method of choice [3-7]. results

This case report describes the rehabilitation of Gunshot wound managed through surgical and prosthodontic principles with gratifying

Keywords: Gun Shot Wound; Reconstruction; Nasolabial Flap; Multidisciplinary approach; Rehabilitation

\section{Introduction}

The available literature on fire arm injuries is voluminous, much of which is debatable or controversial at best. There are many of myths which can be dispelled. Scientific study and practical experience on the battlefield and in emergency rooms have documented the important factors which include projectile type (i.e. jacketed versus non jacketed), shape, victim proximity to muzzle (shot gun injuries), body armor that may have been penetrated, and the specific tissues encountered [8-12]. Unlike the abdomen, pelvis, or many extremity wounds, the maxillofacial region consists of a highly osseous framework with a relatively thin soft tissue drape. The influence of bone fragmentation and secondary missiles is far more prevalent in this region and significantly impacts wound healing and treatment. Numerous authors have proclaimed "treat the wound, not the weapon" [13]. By following this rationale, appropriate surgical treatment principles are adhered to and the wound is individually treated based on presentation and mechanism, rather than an arbitrary adherence to an unsubstantiated classification system. These injuries should be handled in the manner like typical blunt trauma injury is treated: direct open approaches to expose the fractures and debridement of injured soft tissues are followed by reduction, rigid internal fixation, and primary soft tissue closure. Similarly, in perforating injuries the projectile exits the tissue and leaves an entrance and exit wound, which should be managed as described for penetrating injuries. Avulsive wounds demonstrate significant loss of soft or hard tissue and are the result of high energy projectiles (high-velocity rifle or close-range shot gun). Typically, these injuries require multiple operative interventions and true craniofacial principles to reestablish vertical and horizontal facial pillars and anterior projection. Because variable amounts of tissue are lost, primary or secondary grafting is required to replace soft and hard tissue bulk which are common, during rehabilitation of such injuries.

\section{Case Report}

A 25 yrs old serving soldier reported to our center with severe mid facial injury due to Gun shot. On examination he was conscious, alert and oriented to time, place and person. His upper lip was torn in to two (degloving injury of the upper lip), 
nasal aperture shattered, dorsum was injured and his bridge of the nose was flattened (Figure 1). On intra oral examination there was avulsion of Upper anteriors on the right side and the left anteriors of the maxillary arch were fractured. Initially after stabilization the patient was subjected to CT scan and radiographs to rule out any injury to skull, brain and other bony injuries. After confirming there was no bony injury, a multidisciplinary approach was planned for comprehensive management. Patient was taken up under general anesthesia with oral intubation. Initially debridement was done and soft tissue closure was carried out in layers using 3-0 vicryl (Figure 2). The lip and nasal deformities were successfully corrected using a nasolabial flap. An inferiorly based nasolabial flap was designed. In this case the distal end of the flap is thinned by defatting and the distal part is folded and used as an inner lining. The inner layer sutured from proximal to distal by absorbable suture (4-O Vicryl) and the outer layer is sutured by (5-0 Prolene). Care was taken to preserve the intervening skin bridge representing the nasofacial aesthetic line. To maintain the nasal patency and to retain the contour of the dorsum of the nose and nostrils, soft tissue closure was carried out with nasal stents placed inside the nostrils. Pressure dressing was placed and checked postoperatively. Sutures are removed after 5-7 days postoperatively. The right maxillary anteriors, tooth no 11, 12 and 13 which were fractured, avulsed and beyond restorable were extracted (Figure 3). The fractured teeth no 21 and 22 were root canal treated (Figure 4), core build up was done and porcelain fused to metal crown was placed. The missing teeth on the right maxillary arch which were extracted were prosthetically restored by using removable acrylic partial denture (Figure 5). There were multiple surgeries carried out by the Plastic surgery department. The patient underwent successive surgeries to get the final and better soft tissue shape and characteristic for both nostrils. Follow up was done for a period of one year and there were no post-operative or rehabilitative complications (Figure 6).

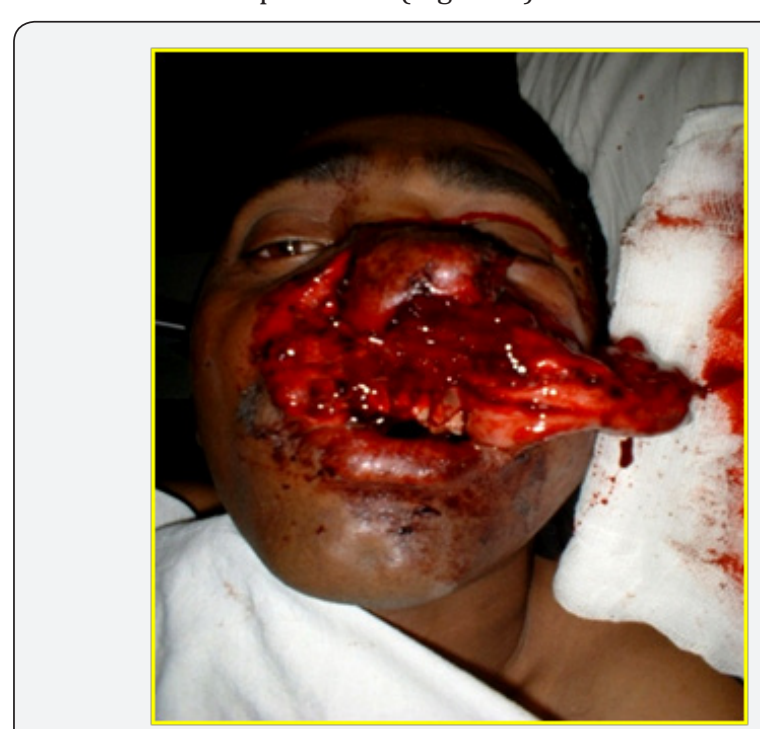

Figure 1: Injured mid face.

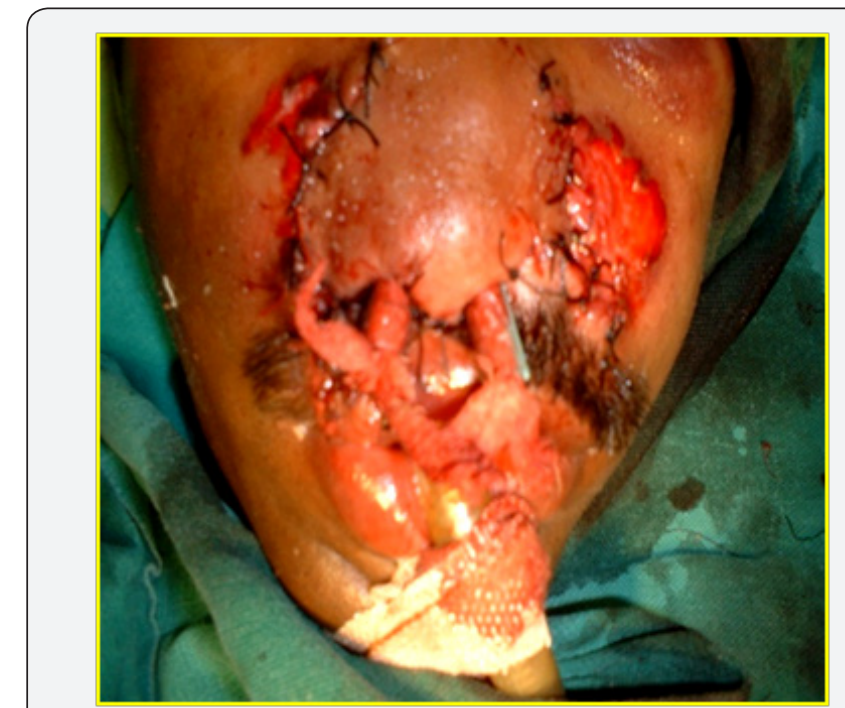

Figure 2: After surgical debridement.

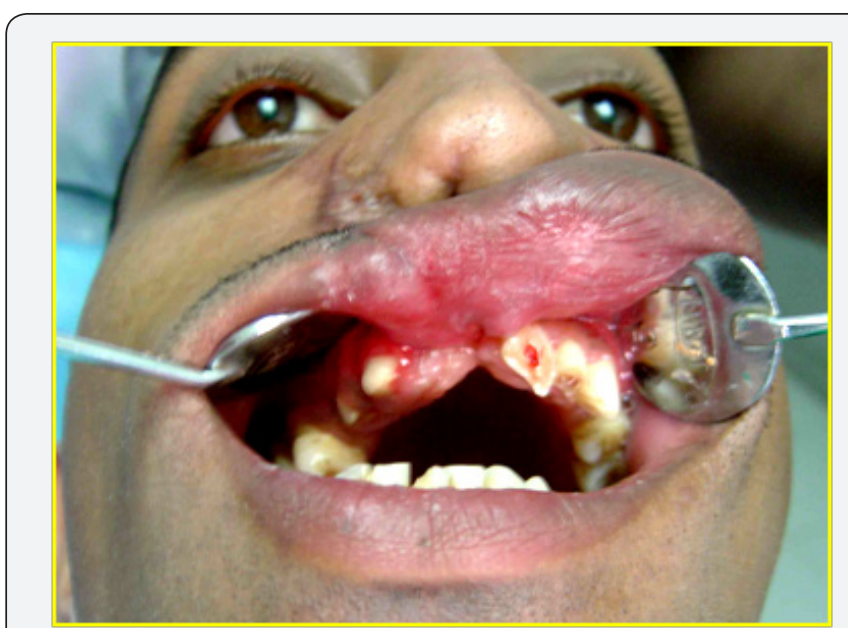

Figure 3: Avulsed anteriors.

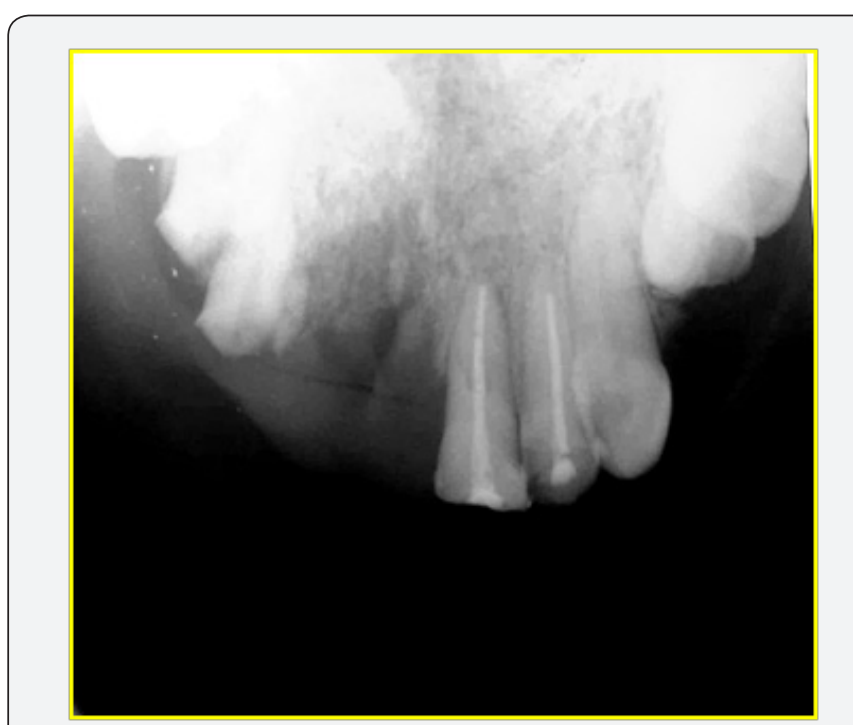

Figure 4: After RCT. 


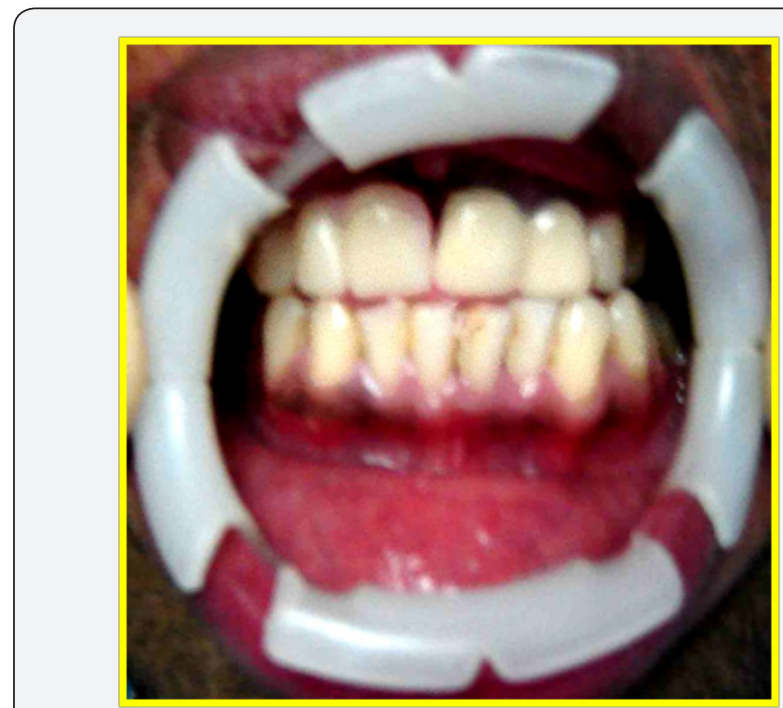

Figure 5: Prosthetic rehabilitation.

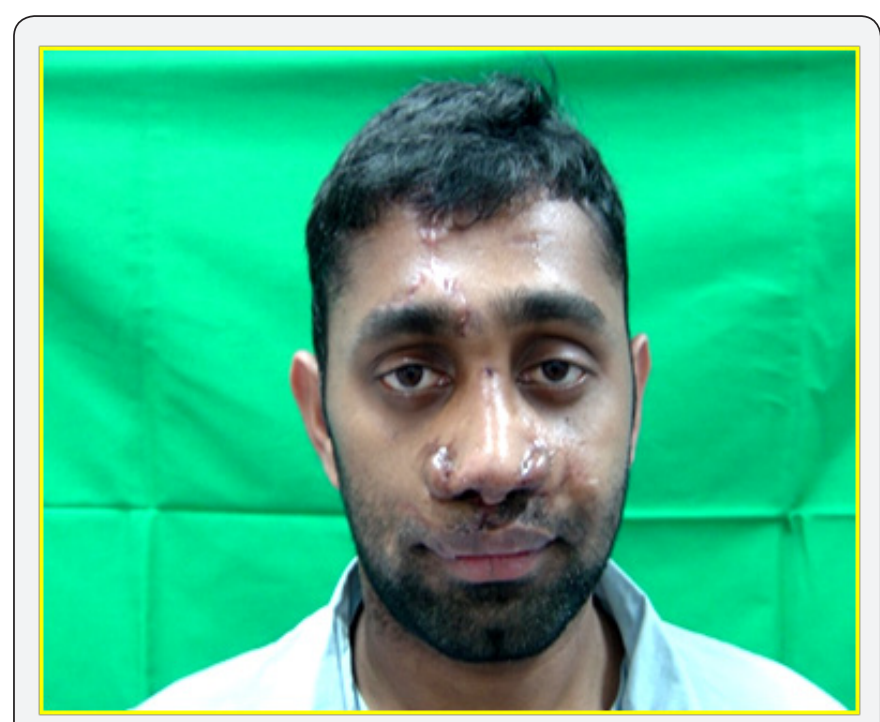

Figure 6: Post op after one year.

\section{Discussion}

Gun Shot wounds have been classified in to three types based on the type of injury caused. They are penetrating, perforating and avulsive [14]. In penetrating wound the projectile does not exit and remains within the target and typically causes soft tissue laceration and possibly bony fracture as all the kinetic energy is transferred to the victim. If the projectile exits it is called as perforating wound. If the projectile exits with substantial loss of tissues it is called as avulsive wound. Recent literature suggests that velocity of impact has been overemphasized and that the most appropriate classification scheme involves either impact energy or the type of firearm involved [10].

Two main treatment protocols exist for these types of wounds. An excellent protocol for management of avulsive injuries to the maxillofacial region has been described by Clark and colleagues,
Robertson and Manson [15-17]. This protocol may be termed as the immediate bone and soft tissue protocol. Briefly, the authors advocate that any high-energy or avulsive injury of the maxillofacial region be approached with a systematic algorithm as follows:

a) Initial debridement and excision of necrotic tissue followed by soft tissue closure and intravenous antibiotic therapy,

b) Repair of bone injury with traditional open reduction and fixation techniques used for blunt facial injuries,

c) Serial debridement every 24 to 48 hours, which involves reopening the soft tissues in the area of avulsion and further debriding interval necrotic tissue, hematoma, infection, and dead space, followed by closure of the soft tissue wound, and

d) Definitive reconstruction with pedicled or free-tissue transfer to replace bone and soft tissue loss when the wound is stable.

Conservative debridement initially is performed to minimize the amount of viable tissue that is excised on first look, yet it ensures through serial debridement, so that all necrotic tissue is eventually removed asit declares. By performing definitive reconstruction early (within the first 2 weeks is recommended), the surgeon is able to take advantage of the primary phase of wound healing and can optimally avoid the detrimental effects of scars and wound contracture that are nearly impossible to overcome. The disadvantage of this protocol is that the surgeon must ensure that the wound bed is free of infection and necrotic tissue before grafting, so that these factors may compromise the graft.

As the projectile enters the victim, the different layers of tissue react according to their specific properties. Injuries to the dermis include abrasion, impaction of particulate matter, and contusion. At closer ranges, burning and implantartion of powder and residue may occur and may result in a tattoo. After the projectile passes through the skin, it next encounters muscle tissue, which is very elastic and may sustain defor $\neg$ mation of as much as four times the diameter of the projectile. On a cellular level, the muscle along the pathway of the projectile becomes devitalized and necrotic. As the projectile travels, it may also encounter other surrounding vital structures such as nerves and blood vessels. The injuries to neurovascular tissue are similar to injuries to muscle. Vessels may be ruptured, crushed, or sheared, and spasm may occur. These injuries may result in hemorrhage and in the formation of thrombi and hematoma. On a cellular level, damage occurs to all three layers of the vessel wall [18].

Sensory and motor nerves may be damaged. When sensory nerves stretch, anesthesia and paresthesia result; when motor nerves stretch, conduction deficit, and loss of func $\neg$ tion result. Injury to bony tissue differs from injury to soft tissues. The minimal projectile velocity required for bone fracture is $65 \mathrm{~m} / \mathrm{s}$. 
Bone is very inelas $\neg$ tic; therefore, the type of injury that occurs depends on the type of bone encountered by the projectile. Injury to cancellous bone usually results in a defect of the drill-hole type. Injury to cortical bone or teeth usually results in shattering. The resulting fragments may act as secondary projectiles and may pose an aspiration risk [19].

The first procedure in definitive maxilᄀlofacial management of a gunshot inju $r$ ry is to irrigate the wound with normal saline. Irrigation debrides any necrotic tissue, removes foreign bodies, and brings the contaminants to nonpatho genic concentrations. Simple cutaneous wounds may be cleansed and dressed with bacitracin or sulfadiazine cream $1 \%$. Shattered bone and teeth along with debris should be removed under copious irrigation. Injuries resulting in active hemorrhage should be explored and repaired at the earliest. At the time of hemorrhage control, obvious nerve damage should also be repaired. Fractures should be treated with open reduction and internal fixation, but such treatment may be a formidable task if there is gross fragmentation. In such cases, closed reduction and intermaxillary fixation is recommended, although not optimal but an acceptable treatment.

\section{Conclusion}

Gunshot wounds should be managed by hemodynamic resuscitation, airway management, and wound care. The step by step treatment methodology will improve and have positive outcome of the treatment. The patient was taken up for staged reconstruction using multidisciplinary specialties of Oral and maxillofacial surgeon, Prosthodontist and Plastic and reconstructive surgeon to successfully rehabilitate has been illustrated in detail. Careful planning and execution as per the treatment plan at the right time shall definitely give the best results.

\section{References}

1. Doctor VS, Farwell DG (2007) Gunshot wounds to the head and neck. Curr Opin Otolaryngol Head Neck Surg 15(4): 213-218.

2. Yuksel F, Celikoz B, Ergun O, Peker F, Açikel C, et al. (2004) Management of maxillofacial problems in self-inflicted rifle wounds. Ann Plast Surg 53(2): 111-117.

3. Motamedi MH (2007) Primary treatment of penetrating injuries to the face. J Oral Maxillofac Surg 65(6): 1215-1218.
4. Thorne CH (1992) Gunshot wounds to the face: current concepts. Clin Plast Surg 19(1): 233-244.

5. Hollier L, Grantcharova EP, Kattash M (2001) Facial gunshot wounds: a 4-year experience. J Oral Maxillofac Surg 59(3): 277-282.

6. Motamedi MH (2003) Primary management of maxillofacial hard and soft tissue gunshot and shrapnel injuries. J Oral Maxillofac Surg 61(12): 1390-1398.

7. McLean JN, Moore CE, Yellin SA (2005) Gunshot wounds to the face: acute management. Facial Plast Surg 21(3): 191-198.

8. Fackler ML, Bellamy RF, Malinowsky JA (1998) A reconsideration of the wounding mechanism of very high velocity projectiles: importance of projectile shape. J Trauma 28(1): S63-S67.

9. Fackler ML (1996) Gunshot wound review. Ann Emerg Med 28(2): 194-203.

10. Fackler ML (1998) Civilian gunshot wounds and ballistics: dispelling the myths. Emerg Med Clin North Am 16(1): 17-28.

11. Santucci RA, Chang YJ (2004) Ballistics for physicians: myths about wound ballistics and gunshot injuries. J Urol 171(4): 1408-1414.

12. Bartlett CS (2003) Clinical update: gunshot wound ballistics. Clin Orthop Relat Res 408: 28-57.

13. Osbourne TE, Bays RA (1997) Pathophysiology and management of gunshot wounds to the face. In: Fonseca RJ, Walker RV (Eds.), Oral and maxillofacial trauma. $\left(2^{\text {nd }}\right.$ edn), Philadelphia: WB Saunders, USA, pp. 948-981.

14. Kelly JF (1977) Management of War Injuries to the Jaws and Related Structures. Washington, DC, US Government Printing Office, USA, p. 36.

15. Clark N, Birely B, Manson PN, Slezak S, Kolk CV, et al. (1996) Highenergy ballistic and avulsive facial injuries: classification, patterns, and an algorithm for primary reconstruction. Plast Reconstr Surg 98(4): 585-601.

16. Robertson B, Manson PN (1998) The importance of serialde'bridement and "second-look" procedures in high energy ballistic and avulsive facial injuries. Operative Techniques in Plastic and Reconstructive Surgery 5: 236-245.

17. Robertson BC, Manson PN (1999) High-energy ballistic and avulsive injuries: a management protocol for the next millennium. Surg Clin North Am 79(6): 1489-1502.

18. Tan YH, Zhou SX, Liu YQ Liu BL, Li ZY (1991) Small-vessel pathology and anastomosis following maxillofacial fire arm wounds: An experimental study. J Oral Maxillofac Surg 49(4): 348-352.

19. Oehmichen M, Meissner C, Konig HG (2000) Brain injury after gunshot wounding: morphometric analysis of cell destruction caused by temporary cavitation. J Neurotrauma 17(2): 155-162. 
This work is licensed under Creative Commons Attribution 4.0 Licens

DOI: 10.19080/JHNSS.2018.02.555576
Your next submission with Juniper Publishers will reach you the below assets

- Quality Editorial service

- Swift Peer Review

- Reprints availability

- E-prints Service

- Manuscript Podcast for convenient understanding

- Global attainment for your research

- Manuscript accessibility in different formats ( Pdf, E-pub, Full Text, Audio)

- Unceasing customer service

Track the below URL for one-step submission https://juniperpublishers.com/online-submission.php 